\title{
Stimulatory Effects of Melatonin on Porcine In Vitro Maturation Are Mediated by MT2 Receptor
}

\author{
Sanghoon Lee, Jun-Xue Jin, Anukul Taweechaipaisankul, Geon-A Kim and Byeong-Chun Lee * \\ Department of Theriogenology and Biotechnology, College of Veterinary Medicine, Seoul National University, \\ 1 Gwanak-ro, Gwanak-gu, Seoul 08826, Korea; sodany2@snu.ac.kr (S.L.); junxue-jin@hotmail.com (J.-X.J.); \\ famfamat@gmail.com (A.T.); pshsje03@snu.ac.kr (G.-A.K.) \\ * Correspondence: bclee@snu.ac.kr; Tel.: +82-2-880-1269; Fax: +82-2-873-1269
}

Received: 27 April 2018; Accepted: 24 May 2018; Published: 26 May 2018

\begin{abstract}
Melatonin is a multifunctional molecule with numerous biological activities. The fact that melatonin modulates the functions of porcine granulosa cells via the MT2 receptor suggests the possibility of MT2 receptor-mediation for melatonin to promote cumulus expansion of porcine cumulus-oocyte complexes (COCs). Therefore, we investigated the presence of MT2 in porcine COCs, and the effects of melatonin with or without selective MT2 antagonists (luzindole and 4-P-PDOT) on this process; COCs underwent in vitro maturation culturing with six different conditions (control, melatonin, luzindole, 4-P-PDOT, melatonin + luzindole or melatonin + 4-P-PDOT). Cumulus expansion, oocyte nuclear maturation, and subsequent embryo development after parthenogenetic activation (PA) were evaluated. In experiment 1, MT2 was expressed in both oocytes and cumulus cells. In experiment 2, melatonin significantly increased the proportion of complete cumulus expansion (degree 4), which was inhibited by simultaneous addition of either luzindole or 4-P-PDOT. A similar pattern was observed in the expression of genes related to cumulus expansion, apoptosis, and MT2. In experiment 3, no significant difference was observed in immature, degenerate, and MII oocyte rates among the groups. In experiment 4, melatonin significantly increased blastocyst formation rates and total blastocyst cell numbers after PA, but these effects were abolished when either luzindole or 4-P-PDOT was added concomitantly. In conclusion, our results indicate that the MT2 receptor mediated the stimulatory effects of melatonin on porcine cumulus expansion and subsequent embryo development.
\end{abstract}

Keywords: melatonin membrane receptor; MT2; melatonin; porcine; in vitro maturation; cumulus expansion

\section{Introduction}

Melatonin ( $N$-acetyl-5-methoxytryptamine), a natural neurohormone synthesized by the mammalian pineal gland, is involved in the regulation of the circadian rhythm [1]. In addition, many other tissues and cells, including bone marrow [2], lymphocytes [3], retina [4], astrocytes [5], thymus [6], and female reproductive organs (granulosa cells, cumulus cells and oocytes) [7], can synthesize melatonin. Evidence indicates that melatonin exists in follicular fluid [8], and that it could be synthesized by the oocytes, as well as that taken up from the blood circulation $[9,10]$. In women, melatonin was suggested as an efficient predictor of positive in vitro fertilization outcomes, and as a medication to enhance oocyte and embryo quality in patients with infertility [11,12].

Melatonin is a potent free radical scavenger and antioxidant [13]; the free radical scavenging activity of melatonin and its metabolites efficiently protects against oxidative stress [14,15]. In addition to direct free radical scavenging, some actions of melatonin are mediated by its two high-affinity $G$ protein-coupled receptors, MT1 and MT2 [16,17]. Although multiple actions of melatonin on a number 
of different physiological processes could be mediated by its antioxidant activity in scavenging free radicals or by melatonin membrane receptors, previous studies explained the stimulatory effects of melatonin on in vitro maturation (IVM) of oocytes mainly by its antioxidant effects $[8,18,19]$. However, a direct action of melatonin on porcine cumulus oocyte complexes (COCs) through melatonin membrane receptors remains unproven. Recently, the existence of melatonin membrane receptors has been shown in the ovaries of mammals [11].

The follicle is the structural and functional unit of the mammalian ovary; it is composed of antral and mural granulosa cell layers attached to the follicular wall, enclosing an oocyte surrounded by cumulus cells [20]. Cumulus cells and granulosa cells were demonstrated to play important roles in metabolic support and follicular steroidogenesis [21,22]. Thus, they are involved in establishing an essential microenvironment for the follicle-enclosed oocyte in coordination with endocrine, paracrine, and autocrine signals [23].

Recently, we reported that melatonin increases porcine cumulus expansion in vitro and subsequent embryo development through the activation of sonic hedgehog signaling [24]. In addition, the presence of mRNAs of melatonin membrane receptors MT1 and MT2 in cumulus cells of pigs was demonstrated [24]. The presence of melatonin membrane receptors in cumulus cells infers that the effects of melatonin on cumulus expansion might be mediated by these receptors. As expansion of the granulosa and cumulus cell layers - which is regulated by hedgehog signaling [25] - is an important process for oocyte maturation [26], the fact that melatonin modulates the functions of porcine granulosa cell through the MT2 receptor [27] suggests that this receptor is likely to mediate the effects of melatonin on porcine cumulus expansion. Therefore, we hypothesized that melatonin could exert stimulatory effects on porcine cumulus expansion through the MT2 receptor. To investigate this, we used selective MT2 antagonists that show substantially higher affinities for MT2 receptors, including luzindole (11 fold) and 4-phenyl-2-propionamidotetralin (4-P-PDOT) (61 fold) [28,29].

Although several studies revealed that melatonin stimulates IVM of oocytes in pigs, whether the underlying mechanism by which melatonin promotes porcine cumulus expansion is receptor-mediated has not been investigated. The aim of this study, therefore, was to investigate whether the effects of melatonin on porcine cumulus expansion are mediated by the MT2 receptor. In this study, we compared the effects of melatonin with or without selective MT2 antagonists (luzindole or 4-P-PDOT) on cumulus expansion, oocyte nuclear maturation, and subsequent embryonic development.

\section{Results}

\subsection{Detection of Melatonin Membrane Receptor 2 (MT2) in Porcine Cumulus-Oocyte Complexes}

In the first experiment, the expression of the MT2 receptor protein in porcine COCs was investigated. Immunofluorescence analysis revealed the presence of the MT2 receptor protein in porcine germinal vesicle (GV) and metaphase II (MII) stage COCs (Figure 1).

\subsection{Effects of Melatonin with or without Selective MT2 Antagonists on Cumulus Expansion}

In experiment 2 , the effects of $10^{-9} \mathrm{M}$ melatonin on cumulus expansion were investigated with or without the selective MT2 antagonists $\left(10^{-9} \mathrm{M}\right.$ luzindole or $10^{-9} \mathrm{M} 4$-P-PDOT) treatment during IVM (Figure 2). Melatonin significantly increased the proportion of COCs exhibiting complete cumulus expansion (degree 4 ) (melatonin, $87.4 \%$ vs. control, $77.5 \%$ ), and decreased the proportion of degrees 2 and 3 compared to the control (melatonin, $5.0 \%$ and $4.8 \%$ vs. control, $9.0 \%$ and $9.4 \%$, respectively). Neither of the selective MT2 antagonists (lunzidole or 4-P-PDOT) treatments affected the degree of cumulus expansion. However, when either luzindole or 4-P-PDOT was added simultaneously with melatonin, they abolished the effect of melatonin on the degree of cumulus expansion. In terms of expression of genes associated with cumulus expansion, apoptosis, and MT2, a similar pattern was observed (Figure 3). Melatonin significantly increased the expression of cumulus expansion genes (Ptgs1, Ptgs2, Has2, Ptx3 and Tnfaip6) and MT2, and decreased the expression of the apoptosis 
gene ( $\mathrm{Bax} / \mathrm{Bcl}-2$ ratio) compared to the control. However, when either luzindole or 4-P-PDOT was included simultaneously with melatonin, the genes whose expression was changed by melatonin were not affected.

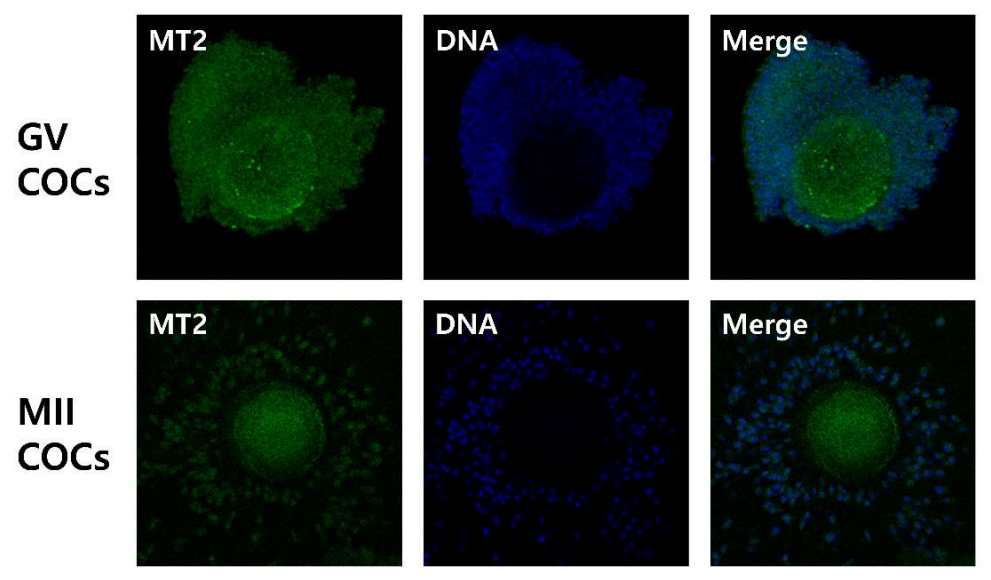

Figure 1. Immunofluorescence images of melatonin receptor 2 (MT2) in porcine germinal vesicle (GV) and Metaphase II (MII) cumulus-oocyte complexes (COCs). Porcine COCs were incubated with MT2 antibodies followed by FITC-conjugated rabbit anti-goat IgG (green). DNA was counterstained with Hoechst-3334. Original magnification $100 \times$.

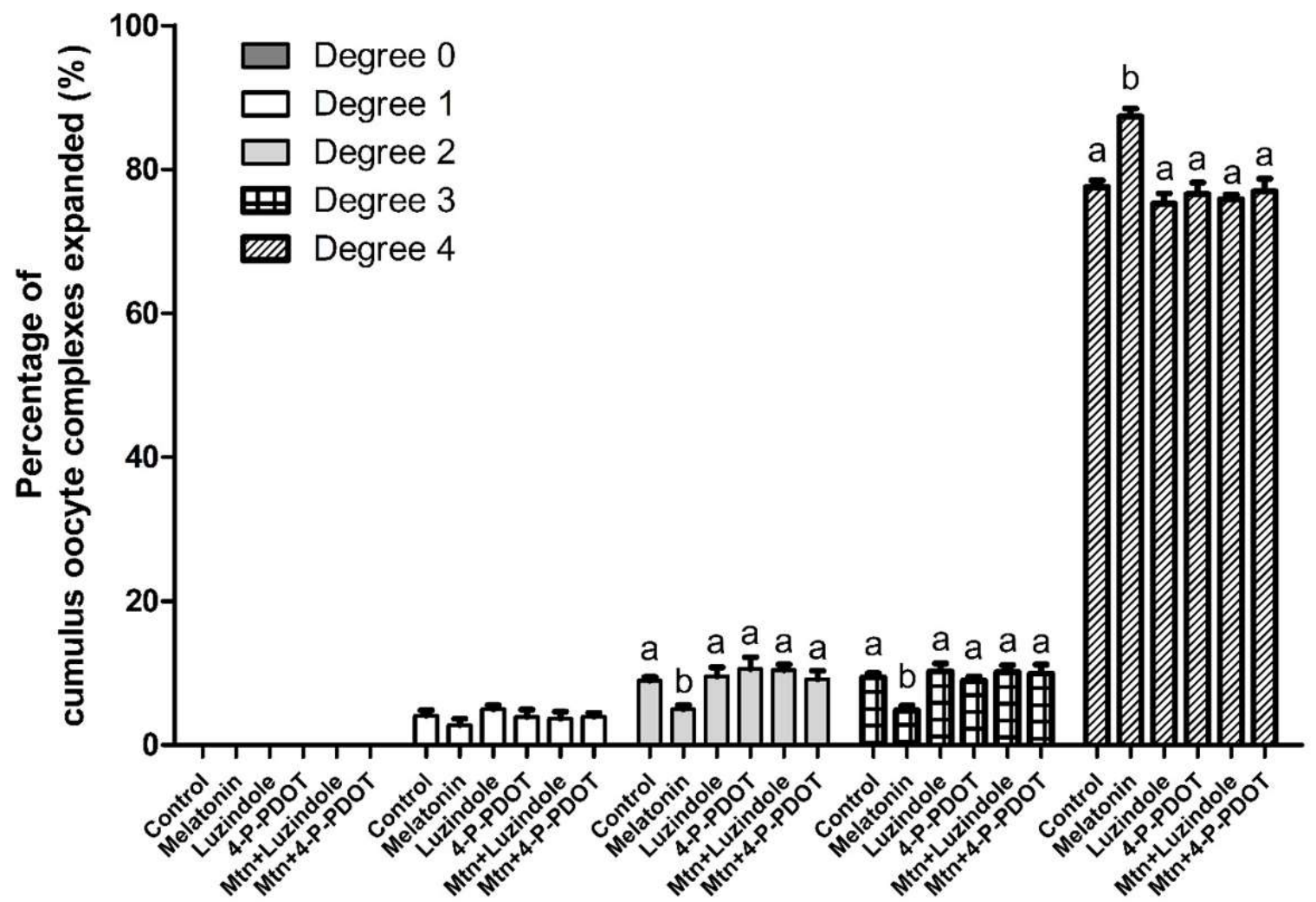

Figure 2. Effects of $10^{-9} \mathrm{M}$ melatonin with or without selective MT2 antagonists $\left(10^{-9} \mathrm{M}\right.$ luzindole or $10^{-9} \mathrm{M} 4$-P-PDOT) on cumulus expansion at $44 \mathrm{~h}$ of IVM. The degree of cumulus expansion was classified into five groups, as described previously [30]. A total of 1344 cumulus-oocyte complexes was used in six independent replicates. Data are shown as the means \pm SEM. Within each category, groups marked with different letters are significantly different $(p<0.05)$. Mtn, melatonin. 
A

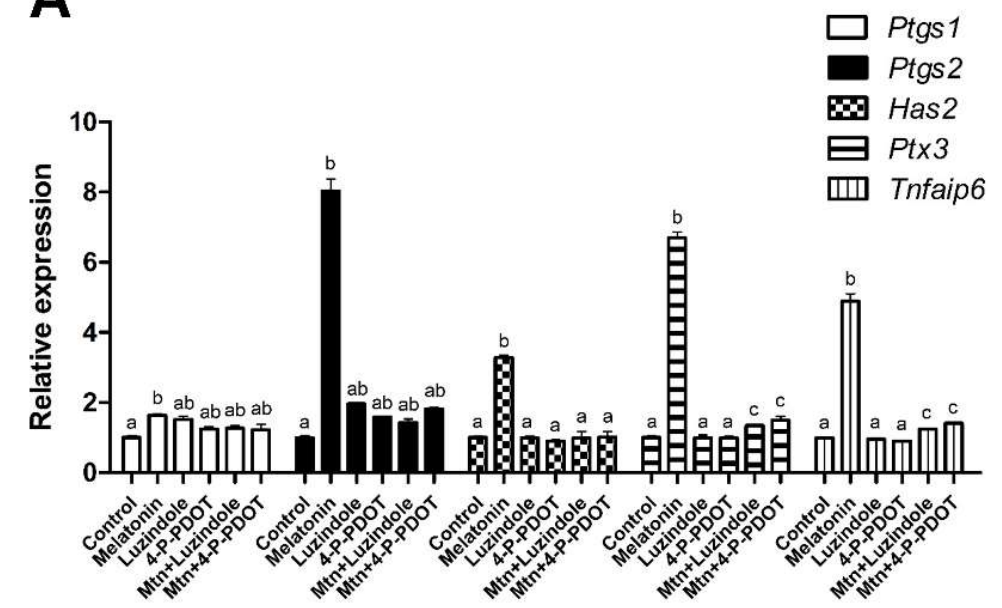

B

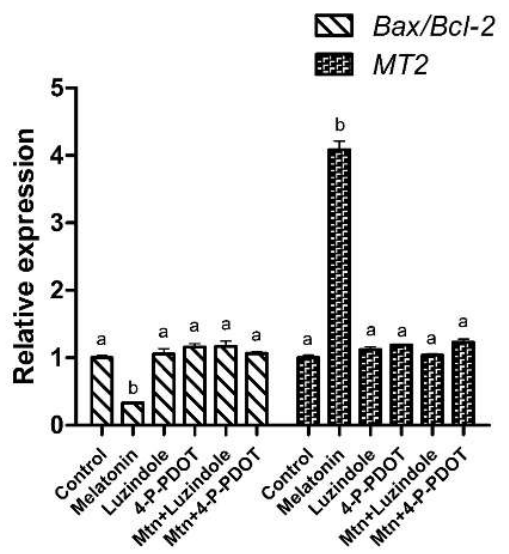

Figure 3. Effects of $10^{-9} \mathrm{M}$ melatonin with or without selective MT2 antagonists $\left(10^{-9} \mathrm{M}\right.$ luzindole or $10^{-9} \mathrm{M} 4-\mathrm{P}-\mathrm{PDOT}$ ) on gene expression in porcine cumulus cells. (A) Cumulus expansion genes (Ptgs1, Ptgs2, Has2, Ptx3 and Tnfaip6); (B) Apoptosis gene (Bax/Bcl-2 ratio) and MT2. Data are shown as the means \pm SEM. Within each category, groups marked with different letters are significantly different $(p<0.05)$. The experiment was replicated at least three times. Mtn, melatonin.

\subsection{Effects of Melatonin with or without Selective MT2 Antagonists on Oocyte Nuclear Maturation}

In experiment 3 , the effects of $10^{-9} \mathrm{M}$ melatonin treatment with or without selective MT2 antagonists $\left(10^{-9} \mathrm{M}\right.$ luzindole or $10^{-9} \mathrm{M} 4$-P-PDOT) during IVM on oocyte nuclear maturation were investigated (Figure 4). Melatonin treatment showed no differences in MII, immature, and degeneration rates, compared to the control. Also, neither luzindole nor 4-P-PDOT treatment affected oocyte nuclear maturation. Even when either luzindole or 4-P-PDOT was added concomitantly with melatonin, oocyte nuclear maturation was not affected.

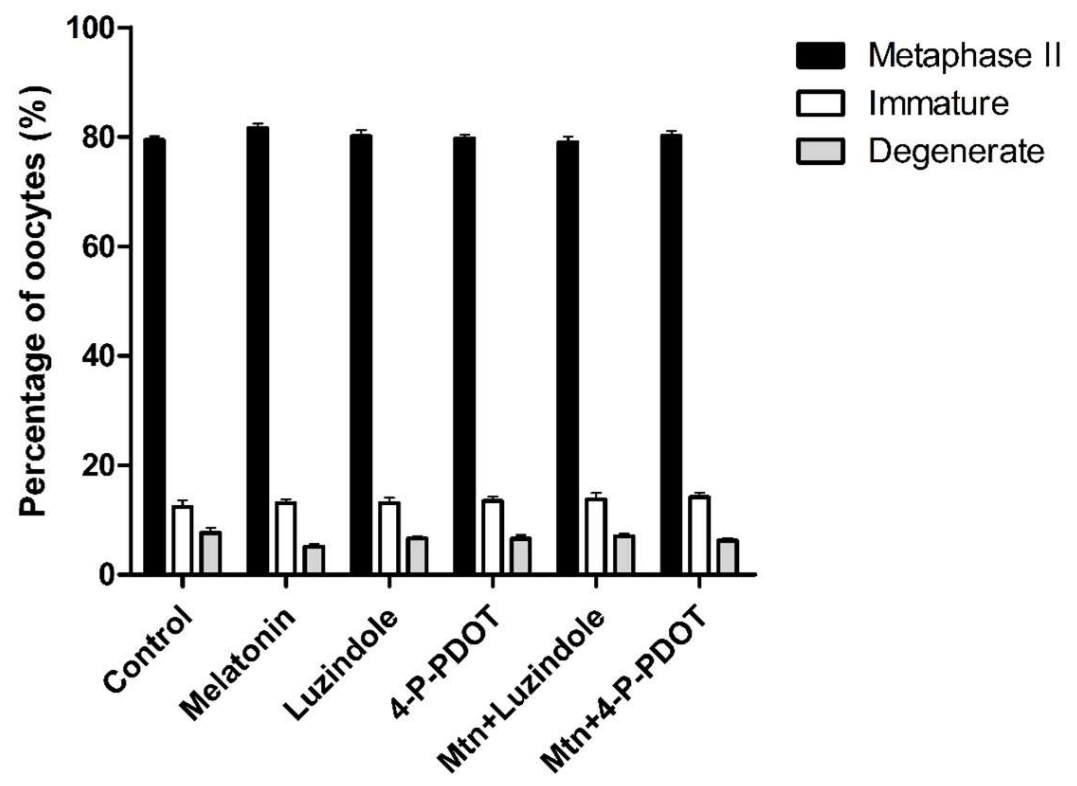

Figure 4. Effects of $10^{-9} \mathrm{M}$ melatonin with or without selective MT2 antagonists $\left(10^{-9} \mathrm{M}\right.$ luzindole or $10^{-9} \mathrm{M} 4$-P-PDOT) on the nuclear maturation of porcine oocytes. A total of 1632 oocytes was used in seven independent replicates. Data are shown as the means \pm SEM. There was no effect of melatonin with or without selective MT2 antagonists on oocyte nuclear maturation. Mtn, melatonin. 
2.4. Effects of Melatonin with or without Selective MT2 Antagonists Treatment during IVM on Subsequent Development of PA Embryos

In experiment 4, we evaluated the effects of $10^{-9} \mathrm{M}$ melatonin treatment with or without selective MT2 antagonists ( $10^{-9} \mathrm{M}$ luzindole or $10^{-9} \mathrm{M}$ 4-P-PDOT) during IVM on subsequent embryonic development after PA (Figure 5). The melatonin treatment group showed a significant increase in blastocyst formation rates and total cell numbers, compared with the control (melatonin, $34.1 \%$ and 66.2 vs. control, $22.3 \%$ and 50.5, respectively). Neither the luzindole nor the 4-P-PDOT group showed a difference in blastocyst formation rates and total cell numbers, compared to the control (luzindole, $22.4 \%$ and $47.5 ; 4-P-P D O T, 20.3 \%$ and 50.7 , respectively). However, when either luzindole or 4-P-PDOT was included concomitantly with melatonin, they abolished the stimulatory effect of melatonin on blastocyst formation rates and total cell numbers (melatonin plus luzindole, $20.8 \%$ and 45.7 ; melatonin plus 4-P-PDOT, 22.1\% and 52.0, respectively).

A
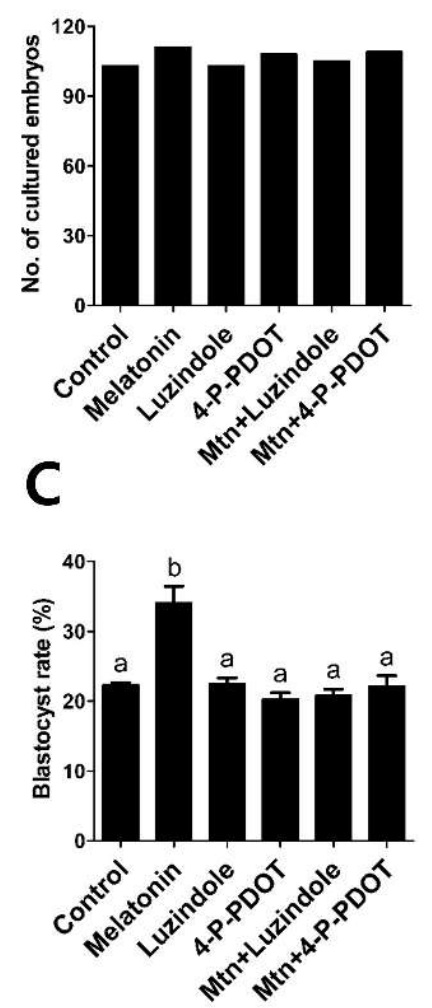

B
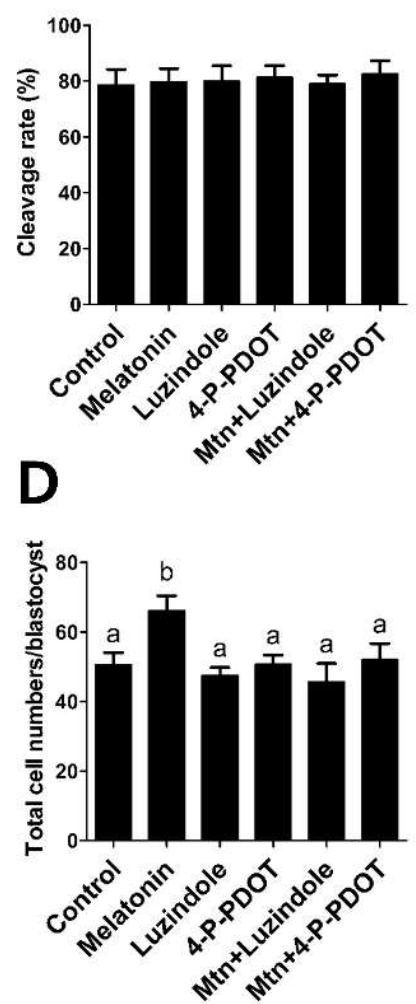

Figure 5. Effects of $10^{-9} \mathrm{M}$ melatonin with or without selective MT2 antagonists $\left(10^{-9} \mathrm{M}\right.$ luzindole or $10^{-9} \mathrm{M} 4$-P-PDOT) during IVM on subsequent embryo development after parthenogenetic activation. (A) Number of cultured embryos; (B) Cleavage rate; (C) Blastocyst rate; (D) Total cell numbers/blastocyst. A total of 639 oocytes was used in four independent replicates. Data are shown as the means \pm SEM. Within each category, groups marked with different letters are significantly different $(p<0.05)$. Mtn, melatonin.

\section{Discussion}

Modulation of functions of porcine granulosa cells by melatonin via the MT2 receptor was demonstrated in a recent study [27]. However, whether the stimulatory effects of melatonin on porcine IVM are meditated by the MT2 receptor was not investigated. In this report, for the first time, we demonstrated that a melatonin-induced improvement in cumulus expansion, expression of genes related to cumulus expansion, apoptosis, and MT2 in cumulus cells and subsequent embryo 
development was prevented by either of the two selective MT2 receptor antagonists (luzindole or 4-P-PDOT). Therefore, our data suggest that the ability of melatonin to promote cumulus expansion and subsequent embryo development is mediated by the MT2 receptor.

As in other organs, some effects of melatonin on the ovary are dependent on conventional membrane receptors (MT1/MT2) [31]. The ovarian follicle is comprised of somatic cells (cumulus cell and granulosa cell layers) surrounding an oocyte [20]. Expansion of the granulosa and cumulus cell layers plays an important role in oocyte maturation [26], and facilitates ovulation in the ovulatory follicle [20]. Recently, we demonstrated that the mRNA of melatonin receptors MT1 and MT2 are expressed in porcine cumulus cells [24]. The presence of melatonin membrane receptors in cumulus cells and the evidence of MT2 receptor-mediated modulation in porcine granulosa cell functions [27] infers that the MT2 receptor could mediate the effects of melatonin on cumulus expansion. To our knowledge, this is the first report to demonstrate the presence of the MT2 receptor protein in porcine GV and MII stage COCs (Figure 1).

The culture conditions during oocyte maturation can dramatically influence the degree of cumulus expansion, the meiotic maturation of oocytes, and the subsequent developmental competence of embryos derived from them [32]. Changes in cumulus expansion and nuclear maturation of porcine COCs are directly associated with subsequent developmental competence of oocytes [33]. Therefore, we evaluated cumulus expansion, nuclear maturation of oocytes, and subsequent embryo development, to investigate whether the MT2 receptor mediates the stimulatory effects of melatonin on IVM, using the selective MT2 antagonists (luzindole or 4-P-PDOT).

Cumulus expansion of porcine COCs was significantly increased by melatonin treatment. Cumulus expansion has been used as a morphological indicator to predict the quality of oocytes following maturation [34], because optimum expansion of the cumulus cell layers is required for proper oocyte maturation [35]. However, when either of the selective MT2 antagonists was added concomitantly with melatonin, the melatonin-induced increase in cumulus expansion was abolished. These results suggested that the ability of melatonin to promote cumulus expansion is likely mediated by the MT2 receptor. To further clarify the mechanisms by which melatonin exerts its stimulatory effects on cumulus expansion, we investigated the expression of genes related to cumulus expansion, apoptosis, and MT2 in cumulus cells. Cumulus expansion genes (Ptgs1, Ptgs2, Has2, Ptx3 and Tnfaip6) which regulate cumulus expansion during oocyte maturation, and $M T 2$, the transcript of melatonin receptor 2, were up-regulated in the melatonin-treated group. An increased expression of cumulus expansion genes and MT2 suggests that MT2 receptor might be responsible for melatonin-induced cumulus expansion. The apoptosis gene ( $\mathrm{Bax} / \mathrm{Bcl}-2$ ratio), which is an indicator of apoptosis [36,37], was decreased by melatonin. This indicates that melatonin inhibited the apoptosis of cumulus cells by regulating the transcripts of proapoptosis, Bax, and antiapoptosis, $\mathrm{Bcl}-2$. However, these changes were prevented in the presence of either of the selective MT2 antagonists (luzindole or 4-P-PDOT). These results suggest that melatonin enhanced cumulus expansion by regulating the expression of cumulus expansion and apoptosis genes via the MT2 receptor. In summary, the effects of melatonin on cumulus expansion, and the expression of cumulus expansion and apoptosis genes, appeared to be mediated predominantly by receptor binding through activation of the MT2 receptor, since luzindole or 4-P-PDOT, selective MT2 antagonists, blocked these effects.

Regarding the effects of melatonin with or without selective MT2 antagonists (luzindole or 4-P-PDOT) on nuclear maturation of porcine oocytes, no significant difference was observed in immature, degenerate, and MII oocyte rates between any treatment group and the control. The absence of any effects on nuclear maturation by melatonin is consistent with a previous study [24]. Also, neither of the MT2 antagonists, luzindole or 4-P-PDOT, affected nuclear maturation of porcine oocytes. Based on these results, we conclude that melatonin or MT2 antagonists have no effect on porcine oocyte nuclear maturation.

To investigate the subsequent embryo development of these treated in vitro matured oocytes, we performed a PA experiment. The results showed that melatonin significantly increased blastocyst 
formation rate and the total cell numbers of PA blastocysts. Blastocyst formation is an excellent indicator of culture system efficiency [38] and embryo development [39]. The total cell numbers of blastocysts is a routine criterion for evaluating embryo quality [40]. However, when either of the selective MT2 antagonists (luzindole or 4-P-PDOT) was added to the IVM culture medium simultaneously with melatonin, the stimulatory effects of melatonin were abolished. Therefore, these results suggest that the MT2 receptor mediates the stimulatory effects of melatonin on the development and quality of PA embryos.

In conclusion, this study provides the first evidence that the stimulatory effects of melatonin on cumulus expansion of porcine COCs, and subsequent embryo development of oocytes, are mediated by the MT2 receptor. These findings will be useful for potential clinical applications, suggesting that the MT2 receptor could be a promising therapeutic target for improving female reproductive capability. However, the specific mechanisms by which melatonin promotes porcine IVM through the MT2 receptor require more intensive research.

\section{Materials and Methods}

\subsection{Chemicals}

All chemicals and reagents used in this study were purchased from Sigma-Aldrich Chemical Company (St. Louis, MO, USA), unless otherwise stated.

\subsection{Oocyte Recovery and In Vitro Maturation}

Ovaries were obtained from prepubertal gilts at a local slaughterhouse, and were transported to the laboratory within $3 \mathrm{~h}$ after collection in physiological saline at $32-35{ }^{\circ} \mathrm{C}$. Cumulus oocyte complexes (COCs) were aspirated from antral follicles ( 3 to $6 \mathrm{~mm}$ in diameter) using an 18-gauge needle fixed to a $10 \mathrm{~mL}$ disposable syringe, and allowed to settle in $50 \mathrm{~mL}$ conical tubes at $37^{\circ} \mathrm{C}$ for $5 \mathrm{~min}$. The supernatant was discarded and the sediment was washed three times in washing medium comprising tissue culture medium (TCM)-199 (Invitrogen, Carlsbad, CA, USA) containing $5 \mathrm{mM}$ sodium hydroxide, $2 \mathrm{mM}$ sodium bicarbonate, $10 \mathrm{mM}$ HEPES, $0.3 \%$ polyvinyl alcohol, and $1 \%$ Pen-Strep (Invitrogen). In each experimental group, approximately 50 COCs were placed into an IVM medium comprising TCM-199 supplemented with $10 \mathrm{ng} / \mathrm{mL}$ epidermal growth factor, $0.57 \mathrm{mM}$ cysteine, $0.91 \mathrm{mM}$ sodium pyruvate, $10 \mu \mathrm{L} / \mathrm{mL}$ insulin transferrin selenium solution (ITS-A) $100 \times$ (Invitrogen), 10\% porcine follicular fluid, $10 \mathrm{IU} / \mathrm{mL}$ eCG, and $10 \mathrm{IU} / \mathrm{mL} \mathrm{hCG}$. The COCs were cultured at $39{ }^{\circ} \mathrm{C}$ in a humidified atmosphere of $5 \% \mathrm{CO}_{2}$. After $21-22 \mathrm{~h}$ of maturation culture with hormone, the COCs were washed three times in fresh hormone-free IVM medium, and then cultured in hormone-free IVM medium for another 21-22 $\mathrm{h}$.

\subsection{Detection of Melatonin Receptor 2 (MT2) in COCs by Immunofluorescence}

Immature or in vitro matured COCs were washed three times in PBS containing 0.2\% PVA, and fixed with $4 \%$ paraformaldehyde $(w / v)$ in PBS for $1 \mathrm{~h}$ at room temperature. After washing three times in PBS with $0.2 \%$ PVA, COCs were permeated with 1\% $(v / v)$ Triton X-100 in PBS for 30 min. Then, COCs were washed three times in PBS with $0.2 \%$ PVA, and blocked with $2 \%$ bovine serum albumin (BSA) in PBS overnight at $4{ }^{\circ} \mathrm{C}$. The COCs were incubated with a primary antibody for MT2 (1:200; ARP64072_P050; Aviva Systems Biology, San Diego, CA, USA) at $37^{\circ} \mathrm{C}$ for $3 \mathrm{~h}$. Subsequently, they were washed three times in PBS with $2 \%$ BSA, and then incubated with a secondary fluorescein isothiocyanate-conjugated anti-rabbit polyclonal antibody (1:200; ab6717, Abcam, Cambridge, UK) at $37^{\circ} \mathrm{C}$ for $1 \mathrm{~h}$ (in darkness). After washing three times in PBS with $2 \%$ BSA, DNA was counterstained with $5 \mu \mathrm{g} / \mathrm{mL}$ Hoechst-33342 for $10 \mathrm{~min}$, and samples were mounted on glass slides. Images were captured with an Eclipse TE200 confocal microscope (Nikon Corp., Tokyo, Japan). 


\subsection{Cumulus Expansion Assessment}

The degree of cumulus expansion was evaluated by microscopic examination, according to Vanderhyden et al. [30]. A degree 0 indicates no detectable expansion, leaving a partially or fully denuded oocyte. A degree 1 indicates the minimum observable expansion, characterized by spherical and compacted cumulus cells around the oocyte. A degree 2 indicates only the outermost layers of cumulus cells expanded. A degree 3 indicates cumulus cells layers expanded up to, but not including the corona radiata. A degree 4 indicates the degree of complete expansion including the corona radiata.

\subsection{Assessment of Nuclear Maturation}

The COCs at 42 to $44 \mathrm{~h}$ after IVM were denuded by gently pipetting with $0.1 \%$ hyaluronidase in Tyrode's albumin lactate pyruvate (TALP) medium. Then, the denuded oocytes were washed three times in TALP medium. The denuded oocytes were assessed under a microscope (TE2000-S, Nikon Corp.) and classified as follows: "immature", oocytes without first polar body extrusion; "degenerate", oocytes with ruptured membrane; "metaphase-II (MII)", oocytes with polar body extrusion.

\subsection{Parthenogenetic Activation (PA) of Oocytes}

After 42 to $44 \mathrm{~h}$ of IVM culture, the COCs were denuded by gently pipetting with $0.1 \%$ hyaluronidase and washed three times in TALP medium. The MII stage oocytes were gradually equilibrated in activation medium consisting of $0.28 \mathrm{M}$ mannitol, $0.5 \mathrm{mM}$ HEPES, $0.1 \mathrm{mM} \mathrm{CaCl} \mathrm{m}_{2}$ and $0.1 \mathrm{mM} \mathrm{MgSO}_{4}$. Oocytes were transferred into a chamber connected to a BTX Electro-Cell Manipulator 2001 (BTX Inc., San Diego, CA, USA) and activated by a single direct current (DC) pulse of $1.5 \mathrm{kV} / \mathrm{cm}$ for $60 \mu \mathrm{s}$. Following electrical activation, the PA embryos were washed three times in fresh Porcine Zygote Medium-5 (PZM-5) (Funakoshi Corporation, Tokyo, Japan), transferred into wells containing $500 \mu \mathrm{L}$ PZM-5 and cultured at $39{ }^{\circ} \mathrm{C}$ in a humidified atmosphere of $5 \% \mathrm{O}_{2}, 5 \% \mathrm{CO}_{2}$ and $90 \% \mathrm{~N}_{2}$ for 7 days.

\subsection{Embryo Evaluation and Total Cell Counts}

The day when PA was performed was designated as Day 0. The embryos were evaluated under a stereomicroscope for cleavage on Day 2 (48 h), and for blastocyst formation on Day 7 (168 h). To determine the total cell numbers of blastocysts, Day 7 blastocysts were washed in TALP medium, and stained with $5 \mu \mathrm{g} / \mathrm{mL}$ Hoechst-33342 for $10 \mathrm{~min}$. Following a final wash in TALP medium, stained blastocysts were mounted on glass slides in a drop of $100 \%$ glycerol, gently flattened with a cover glass, and observed under a fluorescence microscope (Nikon Corp.) at $400 \times$ magnification.

\subsection{Gene Expression Analysis by Real-Time PCR}

Total RNA was extracted from isolated cumulus cells using the easy-spin Total RNA Extraction Kit (iNtRON, Seoul, Korea). Total RNA were equalized for concentration across all the samples, and they were immediately stored at $80{ }^{\circ} \mathrm{C}$ until used real-time PCR. Complementary DNA (cDNA) was synthesized from total RNA using the RNA to cDNA EcoDry Premix, cDNA synthesis kit (Clontech Laboratories Inc., Mountain View, CA, USA). The cDNA was amplified in a $20 \mathrm{~mL}$ PCR reaction in a MicroAmp optical 96-well reaction plate (Applied Biosystems, Singapore) containing $1 \mu \mathrm{L}$ cDNA, $0.4 \mu \mathrm{L}(10 \mathrm{pmol} / \mu \mathrm{L})$ forward primer, $0.4 \mu \mathrm{L}(10 \mathrm{pmol} / \mu \mathrm{L})$ reverse primer, $10 \mu \mathrm{L}$ SYBR Premix Ex Taq (Takara, Otsu, Japan), and $8.2 \mu \mathrm{L}$ of Nuclease-free water (Ambion, Austin, TX, USA). Each sample was performed in at least triplicate. The reactions were performed for 40 cycles, with the following parameters: denaturation at $95^{\circ} \mathrm{C}$ for $15 \mathrm{~s}$; annealing at $60^{\circ} \mathrm{C}$ for $1 \mathrm{~min}$; and extension at $72{ }^{\circ} \mathrm{C}$ for $1 \mathrm{~min}$. Primer sequences, expected product sizes, and GenBank accession numbers for the real-time PCR analysis are presented in Table 1. The expression of each target gene was quantified relative to that of the endogenous control gene $(G A P D H)$. The relative expression $(\mathrm{R})$ was calculated using the following equation:

$$
\mathrm{R}=2^{-[\Delta C \mathrm{t} \text { sample }-\Delta C \mathrm{t} \text { control }]}
$$


Table 1. List of real-time PCR primers.

\begin{tabular}{|c|c|c|c|}
\hline Gene & Primer Sequences $\left(5^{\prime}-3^{\prime}\right)$ & Product Size (bp) & GenBank Accession Number \\
\hline GAPDH & $\begin{array}{l}\text { F: GTCGGTTGTGGATCTGACCT } \\
\text { R: TTGACGAAGTGGTCGTTGAG }\end{array}$ & 207 & NM_001206359 \\
\hline Ptgs1 & $\begin{array}{l}\text { F: CAACACGGCACACGACTACA } \\
\text { R: CTGCTTCTTCCCTTTGGTCC }\end{array}$ & 121 & XM_001926129 \\
\hline Ptgs2 & $\begin{array}{l}\text { F: ACAGGGCCATGGGGTGGACT } \\
\text { R: CCACGGCAAAGCGGAGGTGT }\end{array}$ & 194 & NM_214321 \\
\hline Has2 & $\begin{array}{l}\text { F: AGTTTATGGGCAGCCAATGTAGTT } \\
\text { R: GCACTTGGACCGAGCTGTGT }\end{array}$ & 101 & AB050389 \\
\hline Ptx3 & $\begin{array}{l}\text { F: GGCCAGGGATGAATTTTAC } \\
\text { R: GCTATCCTCTCCAACAAGTGA }\end{array}$ & 185 & NM_001244783 \\
\hline Tnfaip6 & $\begin{array}{l}\text { F: AGAAGCGAAAGATGGGATGCT } \\
\text { R: CATTTGGGAAGCCTGGAGATT }\end{array}$ & 106 & NM_001159607 \\
\hline Bax & $\begin{array}{l}\text { F: TGCCTCAGGATGCATCTACC } \\
\text { R: AAGTAGAAAAGCGCGACCAC }\end{array}$ & 199 & XM_003127290 \\
\hline Bcl-2 & $\begin{array}{l}\text { F: AGGGCATTCAGTGACCTGAC } \\
\text { R: CGATCCGACTCACCAATACC }\end{array}$ & 193 & NM_214285 \\
\hline MT2 & $\begin{array}{l}\text { F: CGGTCGTGTGCTTCTGTTACC } \\
\text { R: AGCAGACGGCGAAGATCA }\end{array}$ & 151 & XM_013979266 \\
\hline
\end{tabular}

F, forward; R, reverse.

\subsection{Experimental Design}

We investigated whether the effects of melatonin on porcine IVM and subsequent embryo development were mediated by the MT2 receptor. Agents were added to the IVM medium during the entire maturation period of $44 \mathrm{~h}$. The concentrations of melatonin $\left(10^{-9} \mathrm{M}\right)$ [24] and selective MT2 antagonists (luzindole and 4-P-PDOT) $\left(10^{-9} \mathrm{M}\right)$ [41] were set according to previous studies, and we designated six groups: (1) control; (2) melatonin; (3) luzindole; (4) 4-P-PDOT; (5) melatonin plus luzindole, or (6) melatonin plus 4-P-PDOT. In experiment 1, we investigated the presence of MT2 receptor protein in porcine COCs. In experiment 2, we investigated the degree of cumulus expansion and expression of genes associated with cumulus expansion, apoptosis and MT2. In experiment 3, we evaluated the oocyte maturation rate. In experiment 4 , we assessed subsequent development of PA embryos.

\subsection{Statistical Analysis}

Statistical analyses were conducted with SPSS 22.0 (SPSS, Inc., Chicago, IL, USA). To determine differences among experimental groups, after normality and homoscedasticity test, the results were analyzed by a Kruskal-Wallis test for data with non-normal distribution or one-way ANOVA for data with normal distribution, followed by a Duncan's multiple range test (when assumption of homoscedasticity was satisfied) or Dunnett's T3 test (when assumption of homoscedasticity was not satisfied). The data are presented as means \pm SEM. $p$ values $<0.05$ were considered to be significantly different.

Author Contributions: S.L. conceived, designed and performed the experiments, and then wrote the manuscript; J.-X.J., A.T. and G.-A.K. discussed the data, read and revised the manuscript; B.-C.L. supervised the research and supplied the funding. All authors read, revised and approved the final manuscript.

Acknowledgments: This study was supported by the Korea Institute of Planning and Evaluation for Technology in Food, Agriculture, Forestry and Fisheries (\#114059-03-3-SB010), The National Research Foundation (2016M3A9B6903410), The Research Institute for Veterinary Science and the BK21 PLUS Program.

Conflicts of Interest: The authors declare no conflict of interest. 


\section{Abbreviations}

Ptgs1 Prostaglandin-endoperoxide synthase 1

Ptgs2 Prostaglandin-endoperoxide synthase 2

Has2 Hyaluronan synthase 2

Ptx3 Pentraxin 3

Tnfaip6 Tumor necrosis factor $\alpha$ induced protein 6

Bcl-2 B cell leukemia/lymphoma 2

Bax Bcl-2 associated $\mathrm{X}$

\section{References}

1. Reiter, R.J. Pineal melatonin: Cell biology of its synthesis and of its physiological interactions. Endocr. Rev. 1991, 12, 151-180. [CrossRef] [PubMed]

2. Tan, D.X.; Manchester, L.C.; Reiter, R.J.; Qi, W.B.; Zhang, M.; Weintraub, S.T.; Cabrera, J.; Sainz, R.M.; Mayo, J.C. Identification of highly elevated levels of melatonin in bone marrow: Its origin and significance. Biochim. Biophys. Acta 1999, 1472, 206-214. [CrossRef]

3. Carrillo-Vico, A.; Calvo, J.R.; Abreu, P.; Lardone, P.J.; Garcia-Maurino, S.; Reiter, R.J.; Guerrero, J.M. Evidence of melatonin synthesis by human lymphocytes and its physiological significance: Possible role as intracrine, autocrine, and/or paracrine substance. FASEB J. 2004, 18, 537-539. [CrossRef] [PubMed]

4. Iuvone, P.M.; Tosini, G.; Pozdeyev, N.; Haque, R.; Klein, D.C.; Chaurasia, S.S. Circadian clocks, clock networks, arylalkylamine $N$-acetyltransferase, and melatonin in the retina. Prog. Retin. Eye Res. 2005, 24, 433-456. [CrossRef] [PubMed]

5. Liu, Y.J.; Zhuang, J.; Zhu, H.Y.; Shen, Y.X.; Tan, Z.L.; Zhou, J.N. Cultured rat cortical astrocytes synthesize melatonin: Absence of a diurnal rhythm. J. Pineal Res. 2007, 43, 232-238. [CrossRef] [PubMed]

6. Naranjo, M.C.; Guerrero, J.M.; Rubio, A.; Lardone, P.J.; Carrillo-Vico, A.; Carrascosa-Salmoral, M.P.; Jimenez-Jorge, S.; Arellano, M.V.; Leal-Noval, S.R.; Leal, M.; et al. Melatonin biosynthesis in the thymus of humans and rats. Cell. Mol. Life Sci. 2007, 64, 781-790. [CrossRef] [PubMed]

7. Reiter, R.J.; Tamura, H.; Tan, D.X.; Xu, X.Y. Melatonin and the circadian system: Contributions to successful female reproduction. Fertil. Steril. 2014, 102, 321-328. [CrossRef] [PubMed]

8. Shi, J.M.; Tian, X.Z.; Zhou, G.B.; Wang, L.; Gao, C.; Zhu, S.E.; Zeng, S.M.; Tian, J.H.; Liu, G.S. Melatonin exists in porcine follicular fluid and improves in vitro maturation and parthenogenetic development of porcine oocytes. J. Pineal Res. 2009, 47, 318-323. [CrossRef] [PubMed]

9. El-Raey, M.; Geshi, M.; Somfai, T.; Kaneda, M.; Hirako, M.; Abdel-Ghaffar, A.E.; Sosa, G.A.; El-Roos, M.E.; Nagai, T. Evidence of melatonin synthesis in the cumulus oocyte complexes and its role in enhancing oocyte maturation in vitro in cattle. Mol. Reprod. Dev. 2011, 78, 250-262. [CrossRef] [PubMed]

10. Sakaguchi, K.; Itoh, M.T.; Takahashi, N.; Tarumi, W.; Ishizuka, B. The rat oocyte synthesises melatonin. Reprod. Fertil. Dev. 2013, 25, 674-682. [CrossRef] [PubMed]

11. Tamura, H.; Nakamura, Y.; Korkmaz, A.; Manchester, L.C.; Tan, D.X.; Sugino, N.; Reiter, R.J. Melatonin and the ovary: Physiological and pathophysiological implications. Fertil. Steril. 2009, 92, 328-343. [CrossRef] [PubMed]

12. Pacchiarotti, A.; Carlomagno, G.; Antonini, G.; Pacchiarotti, A. Effect of myo-inositol and melatonin versus myo-inositol, in a randomized controlled trial, for improving in vitro fertilization of patients with polycystic ovarian syndrome. Gynecol. Endocrinol. 2016, 32, 69-73. [CrossRef] [PubMed]

13. Reiter, R.J. Melatonin: Lowering the High Price of Free Radicals. Physiology 2000, 15, 246-250. [CrossRef]

14. Galano, A.; Tan, D.X.; Reiter, R.J. Melatonin as a natural ally against oxidative stress: A physicochemical examination. J. Pineal Res. 2011, 51, 1-16. [CrossRef] [PubMed]

15. Galano, A.; Tan, D.X.; Reiter, R.J. On the free radical scavenging activities of melatonin's metabolites, AFMK and AMK. J. Pineal Res. 2013, 54, 245-257. [CrossRef] [PubMed]

16. Grossini, E.; Molinari, C.; Uberti, F.; Mary, D.A.; Vacca, G.; Caimmi, P.P. Intracoronary melatonin increases coronary blood flow and cardiac function through beta-adrenoreceptors, MT1/MT2 receptors, and nitric oxide in anesthetized pigs. J. Pineal Res. 2011, 51, 246-257. [CrossRef] [PubMed] 
17. Rivara, S.; Lorenzi, S.; Mor, M.; Plazzi, P.V.; Spadoni, G.; Bedini, A.; Tarzia, G. Analysis of structure-activity relationships for MT2 selective antagonists by melatonin MT1 and MT2 receptor models. J. Med. Chem. 2005, 48, 4049-4060. [CrossRef] [PubMed]

18. Rodrigues-Cunha, M.C.; Mesquita, L.G.; Bressan, F.; Collado, M.D.; Balieiro, J.C.; Schwarz, K.R.; de Castro, F.C.; Watanabe, O.Y.; Watanabe, Y.F.; de Alencar Coelho, L.; et al. Effects of melatonin during IVM in defined medium on oocyte meiosis, oxidative stress, and subsequent embryo development. Theriogenology 2016, 86, 1685-1694. [CrossRef] [PubMed]

19. Li, Y.; Zhang, Z.; He, C.; Zhu, K.; Xu, Z.; Ma, T.; Tao, J.; Liu, G. Melatonin protects porcine oocyte in vitro maturation from heat stress. J. Pineal Res. 2015, 59, 365-375. [CrossRef] [PubMed]

20. Gilchrist, R.B.; Ritter, L.J.; Armstrong, D.T. Oocyte-somatic cell interactions during follicle development in mammals. Anim. Reprod. Sci. 2004, 82-83, 431-446. [CrossRef] [PubMed]

21. Su, Y.Q.; Sugiura, K.; Eppig, J.J. Mouse oocyte control of granulosa cell development and function: Paracrine regulation of cumulus cell metabolism. Semin. Reprod. Med. 2009, 27, 32-42. [CrossRef] [PubMed]

22. Manabe, N.; Goto, Y.; Matsuda-Minehata, F.; Inoue, N.; Maeda, A.; Sakamaki, K.; Miyano, T. Regulation mechanism of selective atresia in porcine follicles: Regulation of granulosa cell apoptosis during atresia. J. Reprod. Dev. 2004, 50, 493-514. [CrossRef] [PubMed]

23. Eppig, J.J. Intercommunication between mammalian oocytes and companion somatic cells. Bioessays 1991, 13, 569-574. [CrossRef] [PubMed]

24. Lee, S.; Jin, J.X.; Taweechaipaisankul, A.; Kim, G.A.; Ahn, C.; Lee, B.C. Melatonin influences the sonic hedgehog signaling pathway in porcine cumulus oocyte complexes. J. Pineal Res. 2017, 63. [CrossRef] [PubMed]

25. Russell, M.C.; Cowan, R.G.; Harman, R.M.; Walker, A.L.; Quirk, S.M. The hedgehog signaling pathway in the mouse ovary. Biol. Reprod. 2007, 77, 226-236. [CrossRef] [PubMed]

26. Marchal, R.; Caillaud, M.; Martoriati, A.; Gerard, N.; Mermillod, P.; Goudet, G. Effect of growth hormone $(\mathrm{GH})$ on in vitro nuclear and cytoplasmic oocyte maturation, cumulus expansion, hyaluronan synthases, and connexins 32 and 43 expression, and GH receptor messenger RNA expression in equine and porcine species. Biol. Reprod. 2003, 69, 1013-1022. [CrossRef] [PubMed]

27. He, Y.M.; Deng, H.H.; Shi, M.H.; Bodinga, B.M.; Chen, H.L.; Han, Z.S.; Jiang, Z.L.; Li, Q.W. Melatonin modulates the functions of porcine granulosa cells via its membrane receptor MT2 in vitro. Anim. Reprod. Sci. 2016, 172, 164-172. [CrossRef] [PubMed]

28. Browning, C.; Beresford, I.; Fraser, N.; Giles, H. Pharmacological characterization of human recombinant melatonin MT(1) and MT(2) receptors. Br. J. Pharmacol. 2000, 129, 877-886. [CrossRef] [PubMed]

29. Tunstall, R.R.; Shukla, P.; Grazul-Bilska, A.; Sun, C.; O'Rourke, S.T. MT2 receptors mediate the inhibitory effects of melatonin on nitric oxide-induced relaxation of porcine isolated coronary arteries. J. Pharmacol. Exp. Ther. 2011, 336, 127-133. [CrossRef] [PubMed]

30. Vanderhyden, B.C.; Caron, P.J.; Buccione, R.; Eppig, J.J. Developmental pattern of the secretion of cumulus expansion-enabling factor by mouse oocytes and the role of oocytes in promoting granulosa cell differentiation. Dev. Biol. 1990, 140, 307-317. [CrossRef]

31. Reiter, R.J.; Rosales-Corral, S.A.; Manchester, L.C.; Tan, D.X. Peripheral reproductive organ health and melatonin: Ready for prime time. Int. J. Mol. Sci. 2013, 14, 7231-7272. [CrossRef] [PubMed]

32. Abeydeera, L.R.; Wang, W.H.; Prather, R.S.; Day, B.N. Maturation in vitro of pig oocytes in protein-free culture media: Fertilization and subsequent embryo development in vitro. Biol. Reprod. 1998, 58, 1316-1320. [CrossRef] [PubMed]

33. Algriany, O.; Bevers, M.; Schoevers, E.; Colenbrander, B.; Dieleman, S. Follicle size-dependent effects of sow follicular fluid on in vitro cumulus expansion, nuclear maturation and blastocyst formation of sow cumulus oocytes complexes. Theriogenology 2004, 62, 1483-1497. [CrossRef] [PubMed]

34. Sutton-McDowall, M.L.; Gilchrist, R.B.; Thompson, J.G. Cumulus expansion and glucose utilisation by bovine cumulus-oocyte complexes during in vitro maturation: The influence of glucosamine and follicle-stimulating hormone. Reproduction 2004, 128, 313-319. [CrossRef] [PubMed]

35. Chen, L.; Russell, P.T.; Larsen, W.J. Functional significance of cumulus expansion in the mouse: Roles for the preovulatory synthesis of hyaluronic acid within the cumulus mass. Mol. Reprod. Dev. 1993, 34, 87-93. [CrossRef] [PubMed] 
36. Nakamura, H.; Kumei, Y.; Morita, S.; Shimokawa, H.; Ohya, K.; Shinomiya, K. Antagonism between apoptotic (Bax/Bcl-2) and anti-apoptotic (IAP) signals in human osteoblastic cells under vector-averaged gravity condition. Ann. N. Y. Acad. Sci. 2003, 1010, 143-147. [CrossRef] [PubMed]

37. Lee, S.; Park, E.J.; Moon, J.H.; Kim, S.J.; Song, K.; Lee, B.C. Sequential treatment with resveratrol-trolox improves development of porcine embryos derived from parthenogenetic activation and somatic cell nuclear transfer. Theriogenology 2015, 84, 145-154. [CrossRef] [PubMed]

38. Ginsburg, E.S.; Racowsky, C. In Vitro Fertilization: A Comprehensive Guide; Springer: New York, NY, USA, 2012; p. 240, ISBN 978-971-4419-9847-7.

39. Nomura, M.; Iwase, A.; Furui, K.; Kitagawa, T.; Matsui, Y.; Yoshikawa, M.; Kikkawa, F. Preferable correlation to blastocyst development and pregnancy rates with a new embryo grading system specific for day 3 embryos. J. Assist. Reprod. Genet. 2007, 24, 23-28. [CrossRef] [PubMed]

40. Knijn, H.M.; Gjorret, J.O.; Vos, P.L.; Hendriksen, P.J.; van der Weijden, B.C.; Maddox-Hyttel, P.; Dieleman, S.J. Consequences of in vivo development and subsequent culture on apoptosis, cell number, and blastocyst formation in bovine embryos. Biol. Reprod. 2003, 69, 1371-1378. [CrossRef] [PubMed]

41. Tian, X.; Wang, F.; He, C.; Zhang, L.; Tan, D.; Reiter, R.J.; Xu, J.; Ji, P.; Liu, G. Beneficial effects of melatonin on bovine oocytes maturation: A mechanistic approach. J. Pineal Res. 2014, 57, 239-247. [CrossRef] [PubMed]

(C) 2018 by the authors. Licensee MDPI, Basel, Switzerland. This article is an open access article distributed under the terms and conditions of the Creative Commons Attribution (CC BY) license (http:/ / creativecommons.org/licenses/by/4.0/). 